IRA-International Journal of Management \& Social Sciences

ISSN 2455-2267; Vol.05, Issue 03 (2016)

Pg. no. 385-401

Institute of Research Advances

http://research-advances.org/index.php/RAJMSS

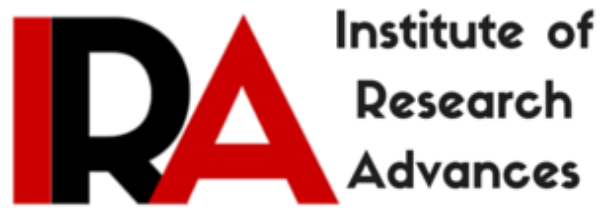

\title{
Determinants of Women Participation and the Implication on Saving and Credit Cooperatives' Development
}

\section{Dr. R. Dayanandan}

Associate Professor, Hawassa University, Ethiopia.

Type of Review: Peer Reviewed.

DOI: http://dx.doi.org/10.21013/jmss.v5.n3.p1

\section{How to cite this paper:}

Dayanandan, R. (2016). Determinants of Women Participation and the Implication on Saving and Credit Cooperatives' Development. IRA-International Journal of Management \& Social Sciences (ISSN 2455-2267), 5(3), 385-401. doi:http://dx.doi.org/10.21013/jmss.v5.n3.p1

(C) Institute of Research Advances

\section{(cc) EY-NO}

This work is licensed under a Creative Commons Attribution-Non Commercial 4.0 International License subject to proper citation to the publication source of the work.

Disclaimer: The scholarly papers as reviewed and published by the Institute of Research Advances (IRA) are the views and opinions of their respective authors and are not the views or opinions of the IRA. The IRA disclaims of any harm or loss caused due to the published content to any party. 


\begin{abstract}
In Ethiopia, promoting gender equality and women empowerment is one of the millennium development goals $(M D G)$ because women play a vital role in the community by taking care of all social activities. Even if women have the talents and skills, cooperatives like other forms of enterprise, reflect the broader society in which they operate, gender imbalances do exist, despite the cooperative principles and values that proclaim equality and equity. It is assumed that, saving and credit cooperatives (SAACOs) can serve the majority of rural people on sustainable base if only they have good performance for which equal participation of women is essential. However, in Dale district the female participation in SACCO is comparatively low. Therefore, to improve the performance of SACCOs and women membership, the major factors which affect the women participation need to be examined. Hence this paper focused on determinants of women participation and the implication of SACCOs in the study area.
\end{abstract}

To address the objectives, both primary and secondary data were used. To collect the primary data, 148 cooperative women members from 13 selected cooperatives which are established during the year 2010 and another 130 non members from the vicinity of selected cooperatives have been identified randomly. Direct interview method was adopted by semi-structured interview schedule to collect the primary data. In addition, focus group discussion and key informant interview also carried out to elicit relevant information pertaining to the research. The collected data was analysed using SPSS (version 20) to arrive meaningful results. Descriptive statistics such as Mean, Standard Deviation, Chi-square Test, and Wilcoxon One Sample Test were used for analysis and interpretation of data. In addition, Binary Logistic Regression model was used to trace out the influential factors responsible for the participation of women in SACCOs in the study area. The analysis results are presented in the form of tabulation and diagrammatic representation.

The outcome of the research shows that overall participation of women members in the affairs of SACCOs is relatively moderate. The overall participation efficiency index value (244.5) which is slightly above the base value of 200 also supports the results. As an average $85.8 \%$ of the sample women is satisfied with the operation and management of cooperatives. Also test of statistics proved that all the variables are significant either $1 \%$ or $5 \%$ level. Logit regression results indicate that out of 12 variables included in the model, 9 variables are found to be highly significant in determining the participation of women in SACCOs. A positive implication of women membership in SACCOs' development also found through test results and is highly significant with the value of 4.27 which is far above the median value of 2. On the basis of findings suitable policy implications are forwarded.

Key words: Women Participation; Determinants; Saving \& Credit Cooperatives; Development

\title{
1. Background
}

The level and distribution of poverty in Ethiopia is extensive. According to Central Statistical Authority (2010/11), about $29.6 \%$ of total population $(20.40 \%$ in urban and $25.70 \%$ in rural areas) is found to be below poverty line. Even though the causes of poverty are many, the lack of financial service and absence of attractive investment opportunities are considered to be the main reasons behind the poverty in Ethiopia. The accessibility of a good financial service is also considered as one of the engines of development (Pinaki, 1998). The country together with development partners, has put poverty reduction strategies high on the agenda. The measure includes the promotion of policies that will encourage accessibility of financial services in the rural area on sustainable base.

Saving allows individuals and/or households to accumulate capital which increase the amount of loanable funds. It also promotes investment which is a base for economic growth and reduction of poverty. 
However in Ethiopia, financial services (saving and credit) to the poor, particularly to the rural poor, appear to be severely limited (Mekonnen et al, 2007). Both Commercial Banks and other formal institutions fail to cater to the credit needs of rural poor (Adera, 1995). The limited access to bank credit, the high interest rates charged by local money lenders and other factors that faced by the rural community led the government of Ethiopia to find alternative rural financial institutions for small farmers, who practice farming on scattered and fragmented plots (Assefa, 1989). The government framed a conducive legal framework and provides considerable resources in promoting and strengthening Saving and Credit Cooperatives (SACCOs) as rural financial institutions and has been using them as a tool of poverty alleviation and development strategy.

Women play a vital role in the community by taking care of all social activities. Being the cornerstone of the family, women can have a great impact not only on the household income, but also on the education of children and avoiding early child deaths, sanitation or improper food or water. Women are striving to improve life for their children and communities, while often facing the harshest circumstances. The equal participation of women in decision making is not only a demand for simple justice on democracy but can also be seen as a necessary condition for women interest to be taken into account. Furthermore, according to studies conducted in sub Saharan Africa, women leaders are less corrupt and more caring about the basic community needs than men (Meron Genene, 2003). However the participation of women in qualified jobs and related fields is at its lowest level. For instance, the National Labor Force Survey (CSA, 2006) indicates that women account for only $23.9 \%$ in technical and professional fields.

Even if women have the talents and skills, cooperatives like other forms of enterprise, reflect the broader society in which they operate, gender imbalances do exist, despite the cooperative principles and values that proclaim equality and equity. Among the most important issues in cooperatives today are women's low level of active participation and their under-representation in decision-making. Women face, more often than not, major obstacles to joining and being active members of typically male-dominated cooperatives. Due to unequal gender norms and relations, women have a lower socio-economic status, compared to their male counterparts, which limits their opportunities to access and participate in formal groups. Their restricted access to, control over, and ownership of land, credit, and information, as compared to men, disadvantage them from meeting conditions of formal group membership and leadership (FAO, 2011; World Bank, 2009).

\section{Statement of the Problem}

In Ethiopia, promoting gender equality and women empowerment is one of the millennium development goals (MDG). Global and national evidence clearly shows that women play critical roles in bringing about food and economic security for their households (FAO, 2011; CSA and ICF International, 2012; Gobezie, 2010; Jones, Tafere, and Woldehanna, 2010). Due to this mounting evidence, greater attention is being paid to ensure that cooperatives policies and programs are gender sensitive and address barriers to women's equal participation and benefit in cooperatives (FAO, 2011; World Bank, 2009; USAID, 2012). Even if this is the aim going to address, women participation in different organizational affairs is low. Women contribute in increasing the cooperatives competitiveness as businesses in the era of globalization and technology. Hand in hand, women help the cooperatives become more aware of and responsive to the members' needs. Women decision-makers can also bring in a more consultative and process-oriented leadership, contrary to men's dictatorial and efficiency-oriented leadership (Alice H. Eagly, 2001). Women are less hierarchical, give value to diversity in viewpoints and in approaches to doing things, and focused on teams. Women's style is actually favored by the new model of leadership that emphasizes empowerment and partnership, collaboration and persuasion instead of domination, cooperation over competition, collectivism over individual action and inclusion over exclusion (ILO promotion of cooperative, 2002).

Due to different obstacles that women face at all levels, the participation of women in SACCOs lags far behind that of men preventing them from taking a full-fledged part in decision making in Ethiopia (Shifra 
Bronznick and Didi Goldenhar, 2008). It is assumed that, SACCOs can serve the majority of rural people on sustainable base if only they have good performance. However, in the study district, in-depth empirical studies show that the performance of SACCOs is far behind the expectation. Different studies indicate that, the performances of SACCOs and members participation are complimentary (Berhane Kidanu, 2008), and members' participation is the major factor for the better performance of SACCOs (Bhuyan, 2004). Moreover, the lack of member patronage leads to poor performance of SACCOs (Sexton and Isknow, 1998). Members are both owners and users of cooperatives and their active participation especially women in a cooperative's business is integral for the success of the cooperatives (Hakelius, 1996). Therefore, to improve the performance of SACCOs, the major factors which affect the women participation in the cooperatives need to be examined. Though, different studies are available on cooperatives in Ethiopia, there is a dearth of studies related to the determinants of women participation and the implication on cooperative development. Hence this research is warranted.

3. Objective: The overall objective of the research paper is to assess the level and the determinants of women participation and the implication on the development of SACCOs. Specific objectives are:

1. To examine the nature and extent of women participation in the selected SACCOs.

2. To trace out the level of women members' satisfaction with the operation and management of SACCOs.

3. To assess the benefits accrued by the women due to the participation in the SACCOs.

4. To identify the factors determining the participation of women in SACCOs.

5. To probe the implication of women participation in the development of SACCOs

\section{Research Design}

The research was carried out in Dale district of Ethiopia and is primarily based on empirical assessment and descriptive in nature. To meet the objectives, primary data was collected from the sample women members of SACCOs and non-members through structured interview schedule (SIS), pre-tested and fine tuned. Five point Likert scale was constructed to measure the satisfaction level of members. Besides, focus group discussions and key informant interview have been carried out for eliciting information and to have authentic support for validating the data.

Multi stage random sampling procedure was adopted to select the zone, district, sample SACCOs and the respondents. At the first stage, Sidama Zone has been selected purposively as the study area. It is justified that Sidama is one of the cooperatively developed zones in the Region wherein significant proportion of population have been brought under the fold of cooperatives of different type. In the second stage, out of 19 districts in the Zone, Dale district has been selected purposively based on the concentration of different types of primary cooperatives. Also in the study area, there are many SACCOs with similar problems mentioned in the problem statement. In the third stage, out of 59 SACCOs found in the study district, SACCOs established in the year 2010 with women members were selected purposively which are 13 numbers with 297 women members. In the final stage to manage the sample size, $50 \%$ of women members from each selected cooperatives was identified randomly which constitute 148. In addition 10 non - women members in the vicinity of the selected cooperatives were also selected randomly based on disproportionate to size sampling procedure. Thus a total of 278 women were formed as the sample population.

Statistical Package for Social Sciences (SPSS version 20) was used for editing, coding, scoring and tabulation of collected data. Statistical tools like Mean, Standard Deviation, and Chi-square Test have applied for analysis and interpretation of data. One-sample Wilcoxon test was carried out to see the significance level to reject or accept the hypothesis. In addition, Logistic Regression model was used to identify the factors determining the participation of women in SACCOs with 19 independent variables.

Model specification: Hosemer and Lemshew (1989) pointed out that a logistic regression has got advantage over others in the analysis of dichotomous outcome variables. Therefore, binary logistic 
regression model is used to study the participation decision behavior of sampled women. In this study, the dependent variable "Participation" has two possible outcomes - probabilities of a woman to be a cooperative member and probability of women to be non-member. Such variables are characterized as dichotomous and outcomes are coded as 1 and 0 respectively.

Binary logistic regression makes no assumption about the distribution of the independent variables. The relationship between the predictor and response variables is not a linear function in logistic regression; instead, the logistic regression function is used, which is the logit transformation of $\mathbf{p}$ :

$\log \left[\frac{p(x)}{1-p(x)}\right]=\alpha+\beta_{1} x_{1}+\beta_{2} x_{2}+\ldots+\beta_{k} x_{k}$

Here $\alpha$ is the "intercept" and $\beta_{1}, \beta_{2}, \beta_{3}$, and so on, are the "regression coefficients" of $\chi_{1}, \chi_{2}, \chi_{3}$ and so on respectively.

The odds of some event happening is defined as the ratio of the probability that the event will occur to the probability that the event will not occur. That is, the odd of an event is given by:

$\operatorname{odd}(E)=\frac{p(E)}{P(\text { not } E)}=\frac{P(E)}{p(1-E)} \ldots$

The odds ratio, which is $\operatorname{Exp}(\beta)$, is the factor by which odds (event) changes for a one unit change in $X$. The odds ratio is a measure of effect size, describing the strength of association or non-independence between two binary data values. It is used as a descriptive statistic, and plays an important role in logistic regression. The estimated odds are simply the ratio of the estimated proportions for the two possible outcomes. If $\hat{P}$ is the proportion for one outcome, then $1-\hat{P}$ is the proportion for the second outcome:

$O D D S=\frac{\hat{P}}{1-\hat{P}}$

This is the ratio of the probability of occurrence of an event to the probability of non-occurrence of the event. Since logistic regression calculates the probability of success over the probability of failure, the results of the analysis are in the form of odds ratio. Logistic regression also provides knowledge of the relationships and strengths among the variables.

\section{Results and Discussion}

The outcome of the research work is presented in the following five sections for easy understanding.

\subsection{Profile of Sample Women Respondents}

The socio economic characteristics of the sample women like age, education, religion, position in the household, occupation, family size, annual income, and landholding are essential aspects which may influence the participation in the cooperatives. Also performance aspects viz., committee membership, savings, credit availement, repayment performance, training attended are the organizational environment which will influence the extent of participation in the cooperative affairs. Hence an attempt has been made to analyze the socio-economic background and performance aspects of the sample respondents and the results are presented in table 1.

Age is the completion of years of the respondents from their birth. If the age increases, due to vast exposure and experience the respondents may gain more knowledge about cooperative values and their importance and as young aged are more dynamic and take more risk, where as the middle aged are having 
a maturity to deal with difficult situation. Also middle aged women may have their own responsibilities and influences in the family and the cooperative society at all aspects (CSA, 2011). It is observed from the results that $38.5 \%$ of the sample SACCOs members and majority $(66.2 \%)$ of the nonmembers belongs to the age between 20-30 years, followed by $35.8 \%$ member and 23.65 non-members belongs to the age category of 30-40 years. The mean age of members is 37.1 and 30.6 for non-members. This shows that most of the respondents under study are youths.

Education molds the people in rational ways and educated members are extra-wards having wide contacts with people taking advantages of their expertise. Also their exposure to mass media enables them to analyse the situation thread-bane and take decision regarding membership in cooperatives. According to Kebede (2011), the low level of education might have significant impact on the low level of participation of women in cooperatives and their role in cooperative performance. It is found from the table (1) results that majority $(66.9 \%)$ of the sample members and $54.6 \%$ of the non-members have attained either primary cycle or secondary cycle of education and around $20 \%$ in both category are illiterates. It was observed during the field study that illiterates were exerting their efforts to participate in cooperative affairs on par with literates.

In human context, family size is a group of people affiliated by consanguinity, affinity or co- residence. As the family size is large, the active participation of women in cooperative is less since women are trapped with lots of workload in the households such as washing clothes, fetching water, bearing children, cooking food and different activities (Kebede G., 2011). The survey results reveal that the mean family size of member respondents is 5.8 and for non-member is 5.4 which is above the national average. This indicates that women need to struggle to manage the family as well as find time to participate in the cooperative affairs.

Table 1: Socio-economic Profile of Sample Respondents

\begin{tabular}{lll}
\hline Variables & Members $(\mathbf{N}=\mathbf{1 4 8})$ & Non-members $(\mathbf{N}=\mathbf{1 3 0})$ \\
\cline { 2 - 3 } Age Category & $57(38.5)$ & $n \mathbf{\%})$ \\
$20-30$ & $53(35.8)$ & $86(66.2)$ \\
$31-40$ & $22(14.9)$ & $31(23.8)$ \\
$41-50$ & $16(10.8)$ & $08(6.2)$ \\
51 and Above & $\mathbf{3 7 . 1}(9.8)$ & $05(3.8)$ \\
Mean (SD) & & $\mathbf{3 0 . 6}(9.4)$ \\
\hline Educational Level & $28(18.9)$ & $27(20.8)$ \\
Illiterate & $09(6.1)$ & $14(10.8)$ \\
Literate & $45(30.4)$ & $32(24.6)$ \\
Primary Cycle(up to grade 4) & $54(36.5)$ & $39(30.0)$ \\
Secondary & $12(8.1)$ & $09(6.9)$ \\
Higher Secondary & - & $09(6.9)$ \\
College, Diploma and Above & & $32(24.6)$ \\
\hline Religion & $34(23.0)$ & $64(49.2)$ \\
Orthodox & $96(64.9)$ & $06(4.6)$ \\
Protestant & $18(12.2)$ & $26(20.0)$ \\
Catholic & - & $02(1.5)$ \\
Muslim & - & $59(45.4)$ \\
Others & & $35(26.9)$ \\
\hline Position in the Household & $63(42.6)$ & \\
Household Head & $02(1.4)$ & \\
Earning Member & & \\
& &
\end{tabular}




\begin{tabular}{|c|c|c|}
\hline Ordinary Member & $07(4.7)$ & $06(4.6)$ \\
\hline Deciding Person & $76(51.4)$ & $30(23.1)$ \\
\hline \multicolumn{3}{|l|}{ Family Size } \\
\hline $1-3$ & $06(4.1)$ & $40(30.8)$ \\
\hline $4-6$ & $95(64.2)$ & $44(33.8)$ \\
\hline $7<$ & $47(31.8)$ & $46(35.4)$ \\
\hline Mean (SD) & $5.8(1.7)$ & $5.4(2.9)$ \\
\hline \multicolumn{3}{|c|}{ Occupation/Sources of Income } \\
\hline Agriculture & $61(41.2)$ & $63(48.5)$ \\
\hline Livestock Rearing & - & $16(12.3)$ \\
\hline Mixed & $77(52.0)$ & $41(31.5)$ \\
\hline Salary & $04(2.7)$ & $08(6.2)$ \\
\hline Business & $06(4.1)$ & $02(1.5)$ \\
\hline \multicolumn{3}{|l|}{ Annual Income } \\
\hline$<5000$ & $45(30.4)$ & $93(71.5)$ \\
\hline $5001-1000$ & $22(14.9)$ & $17(13.1)$ \\
\hline $1001-15000$ & $24(16.2)$ & $02(1.5)$ \\
\hline $15001-20000$ & $15(10.1)$ & $04(3.1)$ \\
\hline$>20000$ & $32(21.6)$ & $04(3.1)$ \\
\hline Mean (SD) & $15276.8(14219)$ & $7876.8(8464.9)$ \\
\hline \multicolumn{3}{|c|}{ Land Holding in Hectare } \\
\hline$<1$ & $95(64.2)$ & $85(65.4)$ \\
\hline $1.01-2$ & $27(18.2)$ & $18(13.8)$ \\
\hline $2.01-3$ & $10(6.8)$ & $07(5.4)$ \\
\hline Above 3 & $06(4.1)$ & $01(.8)$ \\
\hline Mean (SD) & $1.2(0.9)$ & $1.0(0.8)$ \\
\hline
\end{tabular}

Note: Figures within brackets show percentages

Occupation makes the members to pay the savings and loan installments promptly; as a result group members could take repeated loans. Also it will motivate them to exploit the advantage of knowledge from the members for different activities. The survey results indicate that $41.2 \%$ members and $48.5 \%$ non-members are engaged in agriculture and 52\% members and 31.5\% non-members have engaged in mixed type of occupation. This shows that majority of their income sources are both agriculture and livestock rearing.

Income is defined as the flow of cash or equivalents received from work (wage or salary), capital (interest or profit), land (rent) or from the activities undertaken in the land. In this study income is selected and related with participation in SACCOs because if they have sufficient income they will be motivated to be a member to save their money. Table 3.1 results show that mean income of members is higher (Birr 15276.8) than non members (Birr 7876.8) which may be one of the reasons for not to be the member of cooperatives for the later. Also in both cases most of them (30.4\% members and $71.5 \%$ non-members) have below Birr 5000 annual income.

Landholding is defined as the size of land owned by the women households and is more crucial since most of them are engaged in agriculture operation. The survey results mirrored that majority sample women households have up to only one hectare (64.2\% members and $71.5 \%$ non-members) of land.

Position in the Household shows the responsibility of the respondents in the home as well as outside which may influence the membership in cooperatives. It is found that most of them are shouldering the family as household head (42.6\% members and $45.4 \%$ non-members). 


\subsection{Nature and Extent of Participation of Women in SACCOs}

Participation is the informed, autonomous and meaningful involvement of members in cooperatives for influencing decision making and action. Brenda Rosebaum (2002) says that a cooperative can go beyond simply providing an income for the poor women members involved or stimulating the larger community in which it is located, cooperatives have "empowered" women, "enhanced" their dignity, and greatly improved their quality of life. The success of any program and organization depends upon the participation of its users (Lourdes Xavier, 2005). Participation in the general body meeting, discussion in the meeting, election, casting the vote indicates the interest of a member in the affairs of the organization. Research in Thailand during 1978-1988 showed that the appropriate management of member participation is one of the main factors, which leads to the success of cooperatives (Suksawang, 1990).

In interpreting the results for the three point scale questions, the data analyzed by using the frequency and percentages of the respondents participated in each variable. Also to assess the participation efficiency, participatory efficiency index value (PEIV) forwarded by Anwar et al (1997), has been used by considering different indicators such as (a) Attending general meetings; (b) Participation in annual planning; (c) Approving implementation plan; (d) Buying additional shares; (e) Participation in decision making process; (f) Availing Training and education; (g) Availing credit services; (h) Participating in savings; (i) Approval of annual audit report; (j) Voting and (k) Condusting election etc. Finally, onesample Wilcoxon test analysis was carried out to see the significance level to reject or accept the hypothesis.

The formula for participation index $(\mathrm{PI})=$ PnpY0+PopY1+PrpY2. Where,

Pnp $=$ Percentage of respondents with no participation

Pop $=$ Percentage of respondents with occasional participation

Prp $=$ Percentage of respondents with regular participation

$\mathrm{YO}=$ Score assigned to no participation (1)

$\mathrm{Y} 1=$ Score assigned to occupational participation (2)

$\mathrm{Y} 2=$ Score assigned to regular participation (3)

PI $=$ PnpY0 +PopY1+PrpY2

Table 2: Nature and Extent of Participation of Women in SACCOs $(\mathrm{N}=148)$

\begin{tabular}{lllll}
\hline Variables & Never & Occasional & Regular & PI \\
\cline { 2 - 5 } & $n \mathbf{( \% )}$ & $n(\mathbf{\%})$ & $n(\%)$ & 231.5 \\
\hline Attending General Meetings & $21(14.2)$ & $54(36.5)$ & $73(49.3)$ & 241.2 \\
\hline Participation in annual planning & $20(13.5)$ & $47(31.8)$ & $81(54.7)$ & 252.7 \\
\hline Approving implementation plan & $12(8.1)$ & $46(31.1)$ & $90(60.8)$ & 147.9 \\
\hline Buying additional shares & $112(75.7)$ & $01(.7)$ & $35(23.6)$ & 225.2 \\
\hline Participation in Decision making process & $22(14.9)$ & $67(45.3)$ & $59(39.9)$ & 202.9 \\
\hline Availing Training and education & $34(23.0)$ & $76(51.4)$ & $38(25.7)$ & 228.3 \\
\hline Availing credit services & $30(20.3)$ & $46(31.1)$ & $72(48.6)$ & 274.3 \\
\hline Participating in savings & $04(2.7)$ & $30(20.3)$ & $114(77.0)$ & 24.3 \\
\hline Approval of annual audit report & $33(22.3)$ & $46(31.1)$ & $69(46.6)$ & 250.9 \\
\hline Voting & $05(3.4)$ & $63(42.6)$ & $80(54.1)$ & 249.8 \\
\hline Condusting election & $07(4.7)$ & $60(40.5)$ & $81(54.7)$ & $\mathbf{2 4 4 . 5}$ \\
\hline Average & $\mathbf{1 0 ( 6 . 8 )}$ & $\mathbf{6 2 ( 4 1 . 9 )}$ & $\mathbf{7 6 ( 5 1 . 3 )}$ & \\
\hline Note: PI- Partipation & &
\end{tabular}

Note: PI- Participation Index; Figures within brackets show percentages 


\begin{tabular}{l} 
Hypothesis Test Summary \\
\begin{tabular}{|l|l|l|l|}
\hline Null Hypothesis & Test & Decision \\
\hline $\mathbf{1}$ & $\begin{array}{l}\text { The level of Participation is } \\
\text { below average }(<2.0)\end{array}$ & $\begin{array}{l}\text { One-Sample Wilcoxon } \\
\text { Signed Rank Test }\end{array}$ & Rejected the null hypothesis. \\
\hline Asymptotic significances are displayed. The significance level is .01. \\
\hline
\end{tabular} \\
\hline
\end{tabular}

The principle of member's economic participation is advocated by International Cooperative Alliance (1995), which depends up on the contribution of members in the economic affairs of the organization. The overall assessment results indicate that only the moderate level of participation has been observed among the sample members on cooperative affairs. Out of eleven participation variables, above $50 \%$ of the women have participated only in five variables. Below $50 \%$ of the members have participated in the reaming six variables. Majority of the members have participated only in saving since it is mandatory in SACCOs to avail the loan. The overall participation efficiency index value (244.5) which is just above the base value of 200 also shows that the moderate level of participation. Based on the Wilcoxon test results, the null hypothesis is rejected and inferred that the level of women members' participation in the cooperatives' is moderate. Most of them have not participated because almost all members have their own tasks and they are highly busy in day to day activities and they have work load in home as well as they don't have time planning. According to Derib W (2014), as a result of their reproductive roles, women stand little chance of influencing decisions, and even less of being elected to boards or other posts and generally the participation is low. The extent of participation of sample women members also depicted in figure 1.

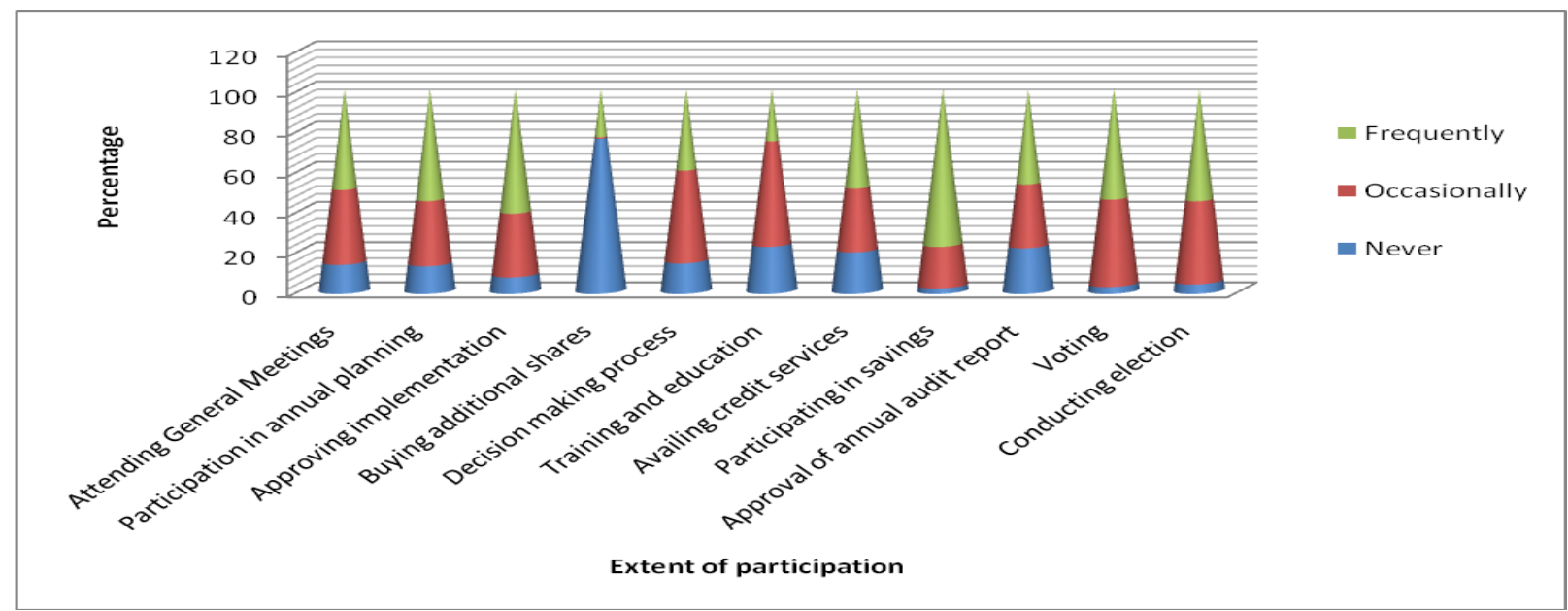

Figure 1: Nature and Extent of Participation of Women in SACCOs $(N=148)$

\subsection{Members' Satisfaction with the operation and management of SACCOs}

Satisfaction is defined as fulfillment of one's wishes, expectations, or needs or the pleasure derived from this. If the members are more satisfied with the activities and the services of SACCOs they would prefer to participate intensively. As cooperatives are member owned, member controlled and member benefited institutions, their main target is to satisfy members' needs in all aspects of their business operations. 
Table 3: Members' Satisfaction with the Operation and Management of SACCOs $(\mathrm{N}=148)$

\begin{tabular}{|c|c|c|c|c|}
\hline \multirow[b]{2}{*}{ Variables } & \multirow{2}{*}{$\frac{\text { Not satisfied }}{n(\%)}$} & \multirow{2}{*}{$\frac{\text { Neutral }}{n(\%)}$} & \multirow{2}{*}{$\frac{\text { Satisfied }}{n(\%)}$} & \multirow[t]{2}{*}{ Test Statistics } \\
\hline & & & & \\
\hline Terms and conditions of savings & $05(3.4)$ & $01(0.7)$ & $142(95.9)$ & $11.3^{* *}$ \\
\hline Interest on savings & $09(6.1)$ & $02(1.4)$ & $137(92.6)$ & $10.6^{* *}$ \\
\hline Period of savings & $03(2.0)$ & $01(0.7)$ & $144(97.3)$ & $11.6^{* *}$ \\
\hline Rate of down payment & $06(4.1)$ & $05(3.4)$ & $137(92.6)$ & $10.9^{* *}$ \\
\hline Amount of credit & $15(10.1)$ & $06(4.1)$ & $127(85.8)$ & $9.4 * *$ \\
\hline Duration of credit & $13(8.8)$ & $08(5.4)$ & $127(85.8)$ & $9.6^{* *}$ \\
\hline Cost of credit & $14(9.5)$ & $09(6.1)$ & $125(84.5)$ & $9.4^{* *}$ \\
\hline Repayment period and conditions & $10(6.8)$ & $11(7.4)$ & $127(85.8)$ & $10.0^{* *}$ \\
\hline Service charge & $04(2.7)$ & $09(6.1)$ & $135(91.2)$ & $11.1^{* *}$ \\
\hline Timely dividend payments & $37(25.0)$ & $52(35.1)$ & $59(39.9)$ & $2.2 *$ \\
\hline Service quality & $18(12.2)$ & $21(14.2)$ & $109(73.6)$ & $8.1 * *$ \\
\hline Conduciveness of service place & $09(6.1)$ & $27(18.2)$ & $112(75.7)$ & $9.4 * *$ \\
\hline Management body election & - & $03(2.0)$ & $145(98.0)$ & $12.0 * *$ \\
\hline Management body capacity & $15(10.1)$ & $14(9.5)$ & $119(80.4)$ & $9.0 * *$ \\
\hline Management body responsibilities & $13(8.8)$ & $10(6.8)$ & $125(84.5)$ & $9.5^{* *}$ \\
\hline Members influence & $06(4.1)$ & $18(12.2)$ & $124(83.8)$ & $10.3^{* *}$ \\
\hline Democracy in cooperatives & $05(3.4)$ & $12(8.1)$ & $131(88.5)$ & $10.8^{* *}$ \\
\hline Election procedure is transparent & $01(0.7)$ & $04(2.7)$ & $143(96.6)$ & $11.8^{* *}$ \\
\hline Access to information & $23(15.5)$ & $41(27.7)$ & $84(56.8)$ & $5.9 * *$ \\
\hline Training accessibility & $33(22.3)$ & $43(29.1)$ & $72(48.6)$ & $3.8^{* *}$ \\
\hline Training relevance & $36(24.3)$ & $42(28.4)$ & $70(47.3)$ & $3.3 * *$ \\
\hline Achieving objectives & $25(16.9)$ & $21(14.2)$ & $102(68.9)$ & $6.8^{* *}$ \\
\hline Solving members problems & $25(16.9)$ & $28(18.9)$ & $95(64.2)$ & $6.4^{* *}$ \\
\hline Qualified leaders & $18(12.2)$ & $22(14.9)$ & $108(73.0)$ & $8.0 * *$ \\
\hline Cooperative principle application & $20(13.5)$ & $24(16.2)$ & $104(70.3)$ & $7.5^{* *}$ \\
\hline Timely scheduled service & $21(14.2)$ & $25(16.9)$ & $102(68.9)$ & $7.3 * *$ \\
\hline Conducting periodical meeting & $24(16.2)$ & $22(14.9)$ & $102(68.9)$ & $7.0 * *$ \\
\hline Average & $03(2.0)$ & $18(12.2)$ & $127(85.8)$ & $10.88 * *$ \\
\hline
\end{tabular}

Note: $* \mathrm{p}<0.05, * * \mathrm{p}<0.01$

For this purpose, 27 important indicators were identified by the researchers based on literature and additional ideas were incorporated from member respondents by open interview, key informants and focus group discussions. The questions were raised among the respondents and their opinion was collected by five point likert scale and converted in to three point scale for analysis as shown in table 3 . To understand the level of satisfaction of women members on SACCOs, descriptive analysis was carried out and Wilcoxon sample test was used to see the significance level.

The overall satisfaction level on the operation and management of SACCOs reveals that majority of the women members are satisfied with the functioning and the services provided with the sample SACCOs in respect of all the selected indicators except one. However only $39.9 \%$ of the sample women members are satisfied with the devidend payment. This indicate that the sample cooperatives are lacking in giving the dividend regularly. As an average $85.8 \%$ of the sample women expressed their satisfaction level positively. Also test of statistics proved that all the variables are significant either $1 \%$ or $5 \%$ level. Hence the null hypothesis is rejected. This shows that the sample cooperatives are operating well in providing services to their members. However, as discussed in the previous section, the participation level of 
women members is moderate due to other reasons. This needs the attention of concerned bodies. To give a clear understanding the satisfaction results are also presented in a diagram form (Figure 2)

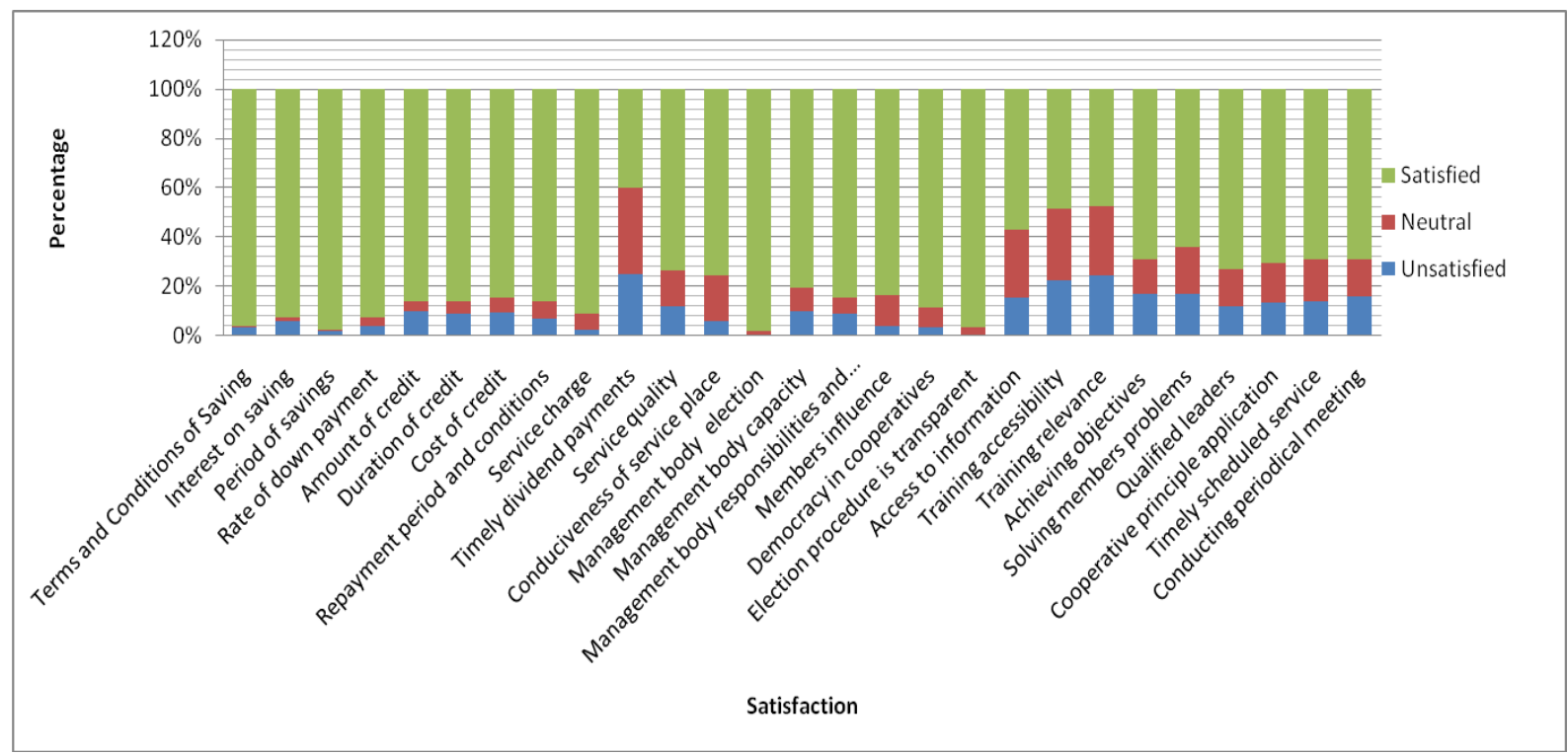

Figure 2: Members' Satisfaction with the operation and management of SACCOs

\subsection{Determinants of Women Participation in SACCOs.}

Women's equal participation in cooperatives is both a women's right and important for sustainable and people-centered development. If cooperatives are gender-responsive and inclusive, they can help women to overcome gender specific constraints to improve their self-confidence, knowledge, leadership skills, income, and access to agricultural inputs, social networks, and position in value-chains. When women are more economically and socially empowered, evidence shows that there are direct and positive impact on women's household and community decision-making power and on access to and control over productive assets. These changes lead to improved household nutrition, food and income security, broader development outcomes, and a more integrated production of both food and cash crops (Qui-sumbing, 2003; FAO, 2011; CSA and ICF International, 2012).

The success of cooperative is strongly related to the target group and member participation (Tips, 1986; $\mathrm{Yu}, 2009)$. Member's commitment to working together and the sense of trust and mutual respect between the managers and members are also important factors (Fulton, 2004). Despite the availability of cooperative societies and efforts of government at all levels, a significant proportion of rural women are either unaware of the existence of such co-operatives or lacking the basic socio-economic characteristics that form the prerequisite for participation in such activities (Idrisa et al., 2007). Hence there is a need to dig out the factors determine the women membership in cooperatives so that adequate policy measures can be forwarded.

Thus to trace out the determinant factors which are responsible for the women to join in the cooperatives, Logit regression analysis was carried out. In this model, participation in cooperatives has been taken as the dependent variable and 19 important variables which were identified through review of literature such as Fund for initial share; Access to resource; Training availability; Access to information; The distance of cooperative; Access to finance/credit; Religion; Household Income; Family size; Educational level; Cultural influence; Freedom in the family; Knowledge about principle of cooperatives; Selfresponsibility; Self confidence; Influence of cooperative members/leaders; Social position; Interest rate for credit etc. were considered as independent variables. Before running the model, Chi-square test was carried out to see the association between each independent variables and the dependent variable. 
Table 4: Chi-square test results on the association between the each independent variables and the dependent variable $(\mathrm{N}=\mathbf{2 7 8})$

\begin{tabular}{lll}
\hline Variables & $\chi^{2}$ & p-value \\
\hline Fund for initial share & $09.16^{*}$ & 0.010 \\
\hline Access to resource & 04.12 & 0.128 \\
\hline Training availability & 0.98 & 0.612 \\
\hline Access to information & $11.27^{* *}$ & 0.004 \\
\hline The distance of cooperative & $07.44^{*}$ & 0.024 \\
\hline Access to finance/credit facility & 04.09 & 0.129 \\
\hline Religion followed & $08.55^{*}$ & 0.014 \\
\hline HH Income & 03.81 & 0.149 \\
\hline Family size & $13.23^{* *}$ & 0.001 \\
\hline Educational level & $18.98^{* *}$ & 0.000 \\
\hline Marital status & $13.40^{* *}$ & 0.001 \\
\hline Cultural influence & $07.05^{*}$ & 0.029 \\
\hline Freedom in the family & $11.50^{* *}$ & 0.003 \\
\hline Knowledge about principle of cooperatives & $8.55^{*}$ & 0.014 \\
\hline Self-responsibility & 02.60 & 0.272 \\
\hline Self confidence & $07.28^{*}$ & 0.026 \\
\hline Influence of cooperative members/leaders & 02.78 & 0.249 \\
\hline Social position & $9.47^{* *}$ & 0.009 \\
\hline Interest rate for credit & 02.98 & 0.225
\end{tabular}

Note: ${ }^{*} \mathrm{p}<0.05, * * \mathrm{p}<0.01$

The results indicate as shown in table 4, twelve variables have found to be statistically significant association with participation of women in the SACCOs. Finally, those twelve variables namely fund for initial share, access to information, the distance of cooperative, religion, family size, educational level, marital status, cultural influence, freedom in the family, knowledge about principle of cooperatives, selfconfidence and social position were included in the logit regression model analysis. The model results are presented in table 5 .

The model results confirm that among the twelve variables, nine variables are found to be significant in determining the women joining in cooperatives. They are (i) Fund for initial capital $(\mathrm{B}=0.609, \mathrm{P}<0.01)$. (ii) Access to information $(\mathrm{B}=0.834, \mathrm{P}<0.01)$; (iii) Distance of cooperative $(\mathrm{B}=0.714, \mathrm{P}<0.1)$; (iv) Religion $(\mathrm{B}=0.735, \mathrm{P}<0.1)$; (v) Family size $(\mathrm{B}=0.820, \mathrm{P}<0.05)$; (vi) Educational level $(\mathrm{B}=0.521, \mathrm{P}<$ 0.05); (vii) Marital status $(\mathrm{B}=-1.405, \mathrm{P}<0.01)$; (viii) Cultural influence $(\mathrm{B}=-.909, \mathrm{P}<0.05)$; (ix) Knowledge about principle of cooperatives $(\mathrm{B}=0.486, \mathrm{P}<0.05)$ etc.

Table 5: Logit Regression Analysis Results $(\mathrm{N}=278)$

\begin{tabular}{lllll}
\hline Variables & B & SE & P-value & Exp(B) \\
\hline Fund for initial share & $.609^{* *}$ & .192 & .001 & 1.839 \\
\hline Access to information & $.834^{* *}$ & .248 & .001 & 2.303 \\
The distance of cooperative & $.714^{* *}$ & .268 & .008 & 2.042 \\
Religion followed & $.735^{* *}$ & .262 & .005 & 2.086 \\
\hline Family size & $.820^{*}$ & .337 & .015 & 2.270 \\
\hline Educational level & $.521^{*}$ & .243 & .032 & 1.684
\end{tabular}




\begin{tabular}{lllll}
\hline Marital status & $-1.405^{* *}$ & .368 & .000 & .245 \\
\hline Cultural influence & $-.909^{*}$ & .349 & .009 & .403 \\
\hline Freedom in the family & -.088 & .261 & .736 & .916 \\
\hline Knowledge about principle of cooperatives & $.486^{*}$ & .229 & .033 & 1.626 \\
\hline Self confidence & .278 & .204 & .174 & 1.321 \\
\hline Social position & .010 & .246 & .969 & 1.010 \\
\hline Constant & -4.705 & .989 & .000 & .009 \\
\hline
\end{tabular}

Note: $B=$ Beta Coefficient, S.E $=$ Standard Error, Exp $(B)=$ Odds Ratio. ${ }^{*} p<0.05$, $* * p<0.01$

The model results explain that if the women have sufficient amount of money to purchase the share, the likelihood of joining in the SACCOs is higher. Also the women who have more information on the advantage of being the member of cooperatives, the probability of membership is high. In the same way, if the cooperatives are located near to their residence, the probability to be a member of SACCOs is more. Likewise religion plays a vital role in deciding themselves to the member of cooperatives. Further if the women have more education, they could assess the importance of being the member of cooperatives to reap the benefits and join voluntarily. In addition marital status also influence in deciding to join cooperatives. Married women may reluctant to join cooperatives due to their household burden. In some extent the culture of the society may not allow the women to participate fully in the cooperative affairs. Finally, those women who have sufficient knowledge about the principles of cooperatives are motivated to be a part of cooperatives which are beneficial to them.

\subsection{Implication of Women Participation in the Development of SACCOs}

Review of literatures show that cooperatives play an important role in job creation by directly providing self-employment to the members and service provision for non-members. Enterprise development and particularly the promotion of small and medium enterprises, has been adopted as a prerequisite and a strategy for job creation and economic growth in a large number of countries (Essien, 2000). Women are the vital force in the society and their participation in the SACCOs is essential to strengthen the functions. In this view, an attempt was made in this research to trace out the opinion of the sample women members regarding how the participation of women in cooperatives helps in development of SACCOs in different angles. For this purpose, 17 statements were forwarded to the member respondents and their opinion was collected through five point Likert Scale and then converted in to three point scale and percentage analysis was carried out to arrive the meaningful results. Finally to see the real implication, Wilcoxon test was conducted to see whether such development have been statistically significant or not. The arrived results are presented in table 6 and figure 3 .

Table 6: Results on Implication of Women Participation in the Development of SACCOs $(\mathbf{N}=148)$

\begin{tabular}{llllllll}
\hline \multirow{2}{*}{ Variables } & \multicolumn{2}{l}{ Disagree } & \multicolumn{2}{c}{ Undecided } & \multicolumn{2}{c}{ Agree } & \multirow{2}{*}{ Test Statistics } \\
\cline { 2 - 8 } & $n$ & $\mathbf{\%}$ & $n$ & $\mathbf{\%}$ & $n$ & $\mathbf{\%}$ & \\
\hline Mobilization of Saving Increased & 50 & 33.8 & - & - & 98 & 66.2 & $3.9^{* *}$ \\
\hline Improved share capital & 51 & 34.5 & 03 & 2.0 & 94 & 63.5 & $3.6^{* *}$ \\
\hline Access to credit & 49 & 33.1 & 01 & 0.7 & 98 & 66.2 & $4.0^{* *}$ \\
\hline Income from credit service & 48 & 32.4 & 02 & 1.4 & 98 & 66.2 & $4.1^{* *}$ \\
\hline Knowledge on cooperative & 46 & 31.1 & - & - & 102 & 68.9 & $4.6^{* *}$ \\
\hline Inculcate saving habits & 46 & 31.1 & 04 & 2.7 & 98 & 66.2 & $4.3^{* *}$ \\
\hline Income source & 48 & 32.4 & 01 & 0.7 & 99 & 66.9 & $4.2^{* *}$ \\
\hline Living standards & 48 & 32.4 & 08 & 5.4 & 92 & 62.2 & $3.7^{* *}$ \\
\hline Members participation & 48 & 32.4 & 07 & 4.7 & 93 & 62.8 & $3.8^{* *}$ \\
\hline Membership in cooperative & 48 & 32.4 & 04 & 2.7 & 96 & 64.9 & $4.0^{* *}$ \\
\hline Skill development & 41 & 27.7 & 02 & 1.4 & 105 & 70.9 & $5.3^{* *}$ \\
\hline
\end{tabular}




\begin{tabular}{|c|c|c|c|c|c|c|c|}
\hline Asset building in cooperatives & 48 & 32.4 & 01 & 0.7 & 99 & 66.9 & $4.2 * *$ \\
\hline Decision making power & 47 & 31.8 & 05 & 3.4 & 96 & 64.9 & $4.1 * *$ \\
\hline $\begin{array}{l}\text { Productivity in the farm } \\
\text { increased }\end{array}$ & 50 & 33.8 & 07 & 4.7 & 91 & 61.5 & $3.5^{*}$ \\
\hline $\begin{array}{l}\text { Participation in community } \\
\text { affairs increased }\end{array}$ & 50 & 33.8 & 05 & 3.4 & 93 & 62.8 & $3.6 * *$ \\
\hline $\begin{array}{l}\text { Awareness increased in } \\
\text { HIV/AIDS and politics }\end{array}$ & 48 & 32.4 & 06 & 4.1 & 94 & 63.5 & $3.9 * *$ \\
\hline Asset building among members & 48 & 32.4 & 01 & 0.7 & 99 & 66.9 & $4.2 * *$ \\
\hline Average & 48 & 32.35 & 04 & 2.8 & 96 & 65.38 & $4.3 * *$ \\
\hline
\end{tabular}

Note: ${ }^{*} \mathbf{p}<0.05, * * p<0.01$

It is found from the analysis results that more than $60 \%$ of the respondents have agreed on the positive implication of women participation in cooperative development in different affairs. The test results also proved that it is highly significant with the value of 4.27 which is far above the median value of 2 . SACCOs' membership will pave the way for improving women's status in many ways such as general economic improvement, skill development and self confidence. Also it facilitates the promotion of livelihood options for the poor women by their access to development agencies, credit and markets. This indicates that women participation in SACCOs is an essential part to increase performance of sample cooperatives. Hence necessary steps are warranted to improve the women membership which paves the way for individual growth as well as society at large.

The outcome of the analysis indicates that as an average, more than $65 \%$ of the women respondents have agreed that the improvement has been observed in all the 17 variables forwarded before them as evidenced from figure 3. From this it can be inferred that there is a positive development in the sample SACCOs due to the women members' participation.

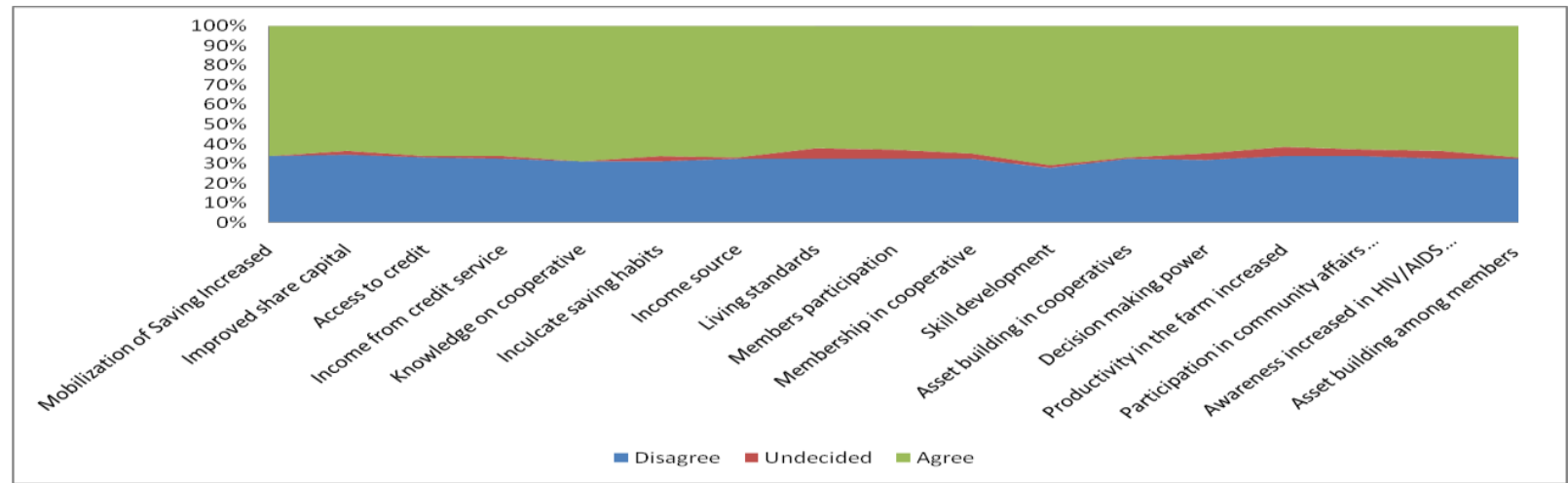

Figure 3: Implication of women participation in the development of SACCOs

\section{Conclusion and Recommendations}

Cooperatives have the advantages of identifying economic opportunities for the women and to defend their interests and providing security to the women by allowing them to convert them individual risks into collective risks. Members may recognize that potential benefits would be achieved over the long term. However, the future survival of cooperatives is directly related to the present active participation of members. Hence the participation of women in SACCOs is imperative not only to improve status of women but also to achieve the well functioning of the cooperatives and its sustainability. However, the low level of women participation has been observed through out Ethiopia in general and the study area in particular due to many reasons. Hence the study focused on assessing the factors that determining women participation in SACCOs of Dale District. 
The major findings of this study revealed that women in SACCOs have limited participation in membership, control and management of the cooperative societies. This was due to the various problems they face as part of the society and as the result of discrimination. Also there is a correlation between women participation and the SACCOs' development has been observed through the investigation. Since the findings revealed the importance of women's participation in SACCOs' development, societies should strengthen and expand their support to resource poor women. Some concrete steps needs to be undertaken by the major intervention agencies namely women's affairs office, cooperative promotion offices and by cooperatives aiming at stimulating the practice of women's involvement. Intervention should be in the areas of women participation in management board, decision making, gender equality and awareness creation and the socio-cultural attitude of the people towards women. Cooperatives have to convert inactive and potential members to actively participated membership, thus qualified and competent leadership and management must be groomed up to solve these problems.

Based on the findings following recommendations are forwarded

- As women in the study area face multiple burdens in the domestic household, attitudinal and behavioural change in the community is essential to share the responsibilities so that they will get enough time to participate in the cooperative affairs.

- The study found that women's education and training was very low and they should be educated and trained on cooperative values and principles, by-laws, rights and obligation, rules and regulations as well as the opportunity of being membership among potential members.

- One of the main problems identified by this study is low participation of women in planning, decision making process, implementation and evaluation of business activities in the selected SACCOs. Therefore, the SACCOs should create opportunities for the women in the said activities and motivating them to participate all affairs of the cooperatives.

- In order to improve the membership of women in SACCOs, awareness campaign has to be conducted by the extension workers and the cooperative workers through propaganda, film show and drama show about the benefits of cooperatives so that they may have positive attitude towards participation in SACCOs.

- In order to increase the participation in the meetings regularly, paying their dividends on time is essential.

- Result has showed that the members and non members were highly influenced by the group they refer who has interaction with the cooperatives. Therefore, members who are in the SACCOs have to be a good example for others by improving their life status through utilizing effectively the benefit they earn from the membership.

- Most of the sample in the study area are depends on their income from agriculture and allied activities. Non-farm activities among women have to be inculcated so as to earn additional income which will be the source for purchase shares and to be member in SACCOs.

- One of the determinant variables found through regression analysis is access to information. Hence provision of sufficient information on SACCOs' functions and its benefits to the women in the society to improve the membership is essential.

- Only $30.4 \%$ of the sample women are found to be in the managerial positions of selected SACCOs which are to be increased by proper reservation.

- It is found through the survey that only $1.4 \%$ of the sample members have got information regarding the importance of cooperatives through media. Hence promotion through media is to be improved. 


\section{References}

- Adera A. (1995). Instituting effective linkages between formal and informal financial sector in Ethiopia, Program and Operations Assessment Report No. 10, USAID, Washington.

- Alice H. Eagly. (2001). The Leadership styles of women and men, Department of Psychology, North Western University, USA.

- Assefa A. (1989). Role of financial cooperatives in alleviating poverty in Ethiopia, Self Help Development International, Addis Ababa, Ethiopia.

- Berhane Kidanu (2008). Factors affecting the development of SACCOs in Ethiopia, A case study of two districts, Ethiopian Journal of Development Research, 11(1), Addis Ababa, Ethiopia.

- Bhuyan A, (2004), Some Factors Influencing Agricultural Credit among Peasant Farmers in Ethiopia: A case study of two district, Ethiopian Journal of Development Research, 11 (1), Addis Ababa, Ethiopia.

- Central Statistical Authority (CSA), (2011), Welfare Monitoring Survey: Statistical Report Indicators on Living Standard, Addis Ababa, Ethiopia

- Central Statistical Authority (CSA), (2006), Population projection based on the population and housing census of Ethiopia, Volume, 1 , Statistical Report on population size, Addis Ababa, Ethiopia.

- Derib W., Nega E. (2014). Participation of Women in Rural Cooperatives: Evidence from Gewane and Fentale Districts of Afar Region, Ethiopia. Journal of Economics and Sustainable Development, 5 (15), Wolaita Sodo University, Ethiopia

- Essien, U. D. (2000). Poverty Alleviation Program: A Positive Step Toward the Development of Human Resources, African Journal of Business and Economic Research, Vol. 1(19), pp. 13-20.

- Food And Agriculture Organization (2011) Cooperatives: A path ways to Women's Empowerment in Rural Areas, $16^{\text {th }}$ International Day of Cooperative, Hawassa, Ethiopia.

- Federal Cooperative Agency Report (FCA, 2012), Addis Ababa, Ethiopia

- Fulton, J. (Ed.). (2004). Understanding Cooperative Behavior: The Prisoners' Dilemma Approach. New York: M.E. Sharpe.

- Gobezie, G. (2010). Empowerment of Women in Rural Ethiopia: A review of Two Microfinance Models. Praxis: The Fletcher Journal of Human Security, XXV, pp23-38.

- Hakelius B (1996). Micro Finance and Poverty Reduction, Oxfam (UK and Ireland) and Action Aid

- Idrisa L., Sulumbe M., Mohammed T. (2007). Socio-Economic Factors Affecting the Participation of Women in Agricultural Cooperatives in Gwoza Local Government, Borno State, Nigeria, Journal of Agriculture, Food, Environment and Extension.

- International Co-operative Alliance, (1995), Statement on the Co-operative identity, Manchester.

- International Labor Organization (ILO) (2002), Legal constraints to women's participation in cooperatives, compilation of 11country studies in Asia, Africa and Latin America, Cooperative Branch, Ulaanbaatar, Mongolia.

- Kebede G. (2011). Women's Participation in Cooperatives: The Case of Gedeb Hassasa Farmer's Multipurpose Cooperative Society in Arsi Zone, Oromiya, Ethiopia. MA Thesis, Mekelle University.

- Lourdes, (2005). Role of Cooperatives in Tribal Development: A Study in Andaman and Nicobar Islands, Dissertation, P.G. Development of Cooperation, collage of Arts \& Science

- Mekonnen K, Alemayhu G, Yisehak M, Haftu D. (2007). Development in Saving and Credit Cooperatives in Ethiopia: Evolution, Performance, Challenges and Interventions, RUFIP Occasional paper No.4, Addis Ababa.

- Meron Genene, (2003). Gender and Leadership, Paper presented at the conference entitled "Bridge Building between Ethiopia and Austria", organised by Äthiopisch-Österreichische Frauensolidarität and Österreichisch-Äthiopische Gesellschaft, Vienna, Austria. 
- National Report, (2004). Progress made in the Implementation of the Beijing Plat form for Action, Prime Minister Office/Women Affairs Sub Sector, Addis Ababa, Ethiopia.

- Pinaki, B. (1998). Formal and Informal sector interaction in rural credit markets. Journal of Development Economics, 56: pp 265-280

- Quisumbing, A., ed. (2003). Household Decisions, Gender and Development: A Synthesis of Research. International Food Policy Research Institute, Washington, DC.

- Sexton G and Isknow E (1998). Rural Finance guiding Principles, GTZ, Eschborn

- Shifra Bronznick and Didi Goldenhar, (2008). $21^{\text {st }}$ Century Women's Leadership, Research Center for Leadership in Action, NYU Wagner.

- SNNP Region, Marketing and Cooperative Agency (2011). Annual Report, Hawassa

- Suksawang, O. (1990). Dynamics of cooperative development, from www.systemdynamics.org/conferences/1990/proceed/pdfs/suskal102.pdf. on 25th May 2015

- Tips, W. (1986). Implementation problems of co-operatives promotion in Thailand: a survey of the opinion of officials of the RTG Co-operatives Promotion Department: Division of Human Settlements Development, Asian Institute of Technology.

- USAID. (2012). Promoting Women in Cooperatives in Ethiopia: for Agricultural Value Chains Development. Report of Consultation held in Addis Ababa, January 25-26, 2012

- World Bank. (2009). Gender in Agriculture. Sourcebook. Washington, DC: World Bank.

- Yu, R. (2009). Four factors influence farmer cooperative development. Retrieved on April 5, 2015, from http://nc.mofcom.gov.cn/news/11410711.html. 